\title{
Rancang bangun sistem penangkap sampah Daerah Aliran Sungai (DAS) berbasis integrasi screw conveyor dan sistem pemantauan menggunakan Internet of Things (IoT)
}

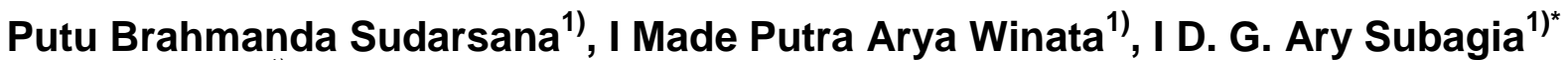 \\ ${ }^{1)}$ Program Studi Teknik Mesin Fakultas Teknik Universitas Udayana
}

Naskah diterima 15/04/2021; direvisi 24/07/2021; disetujui 30/08/2021

doi: https://doi.org/10.24843/JEM.2021.v14.i01.p01

\begin{abstract}
Abstrak
Sampah yang mengalir di sungai menimbulkan beberapa masalah di berbagai aspek, terutama pada aspek lingkungan. Salah satu mekanisme penangkapan sampah yang banyak diterapkan adalah rak sampah. Namun, studi menunjukkan bahwa rak sampah berpotensi menghalangi aliran sungai yang meningkatkan resiko bencana banjir. Penelitian ini mengajukan mekanisme penangkapan sampah berbasis screw conveyor dengan variasi desain bilah menyerupai rak sampah terintegrasi sistem pemantauan menggunakan internet of things. Penelitian dilakukan melalui tiga metode secara virtual prototyping, metode perancangan desain CAD (Computer-Aided Design) melalui kalkulasi elemen mesin dan desain 3 dimensi pada software Autodesk Inventor Professional 2018, metode analasis desain meliputi analisis computational fluid dynamics dan analisis tegangan tiga dimensi menggunakan ANSYS, serta metode perancangan dan pengujian sistem monitoring dengan perangkat open-source NodeMCU dan real-time database Google Firebase. Perancangan desain CAD memperoleh desain dan spesifikasi komponen screw conveyor, sistem transmisi v-belt, ball contact bearing, serta motor listrik dengan kapasitas penangkapan sampah sebesar $0,368 \mathrm{~m}^{3} / \mathrm{s}$. Hasil validasi desain menunjukkan kecepatan aliran air saat melewati geometri desain tidak berkurang secara signifikan serta mampu menahan kombinasi beban self-load dan beban tekanan akibat aliran air. Website monitoring telah mampu menampilkan data yang diakusisi sensor secara real-time.
\end{abstract}

Kata Kunci: sampah sungai, screw conveyor, CAD/CAE, elemen mesin, internet of things.

\begin{abstract}
Waste material flowing in rivers creates several problems in various aspects, especially in environmental aspects. One of the waste-capturing mechanisms which is widely applied is the trash rack. However, studies show that trash racks have the potential to block river flow which increases the risk of flooding. This study proposes a screw conveyor-based waste capturing mechanism with a modification of the blade's design resembling a trash rack and integrated with monitoring system using the internet of things. The research was conducted through three methods of virtual prototyping, the CAD (Computer-Aided Design) design method through calculation of machine elements and 3-dimensional design process using Autodesk Inventor Professional 2018 software, the design analysis method which includes computational fluid dynamics analysis and threedimensional stress analysis using ANSYS software, as well as methods for designing and testing monitoring systems using the open-source NodeMCU board and Google Firebase real-time database. The result obtained from this research are the design and specifications of screw conveyor components, v-belt transmission systems, ball contact bearings, and electric motors with a waste-capturing capacity of $0.368 \mathrm{~m}^{3} / \mathrm{s}$. The results of the design validation show that the velocity of water flowing through the design geometry is not significantly reduced and the design is able to withstand a combination of self-load and pressure loads due to water flow. The monitoring website has been able to display real-time sensor-acquired data.
\end{abstract}

Keywords: trash in river, screw conveyor, CAD / CAE, machine elements, internet of things.

\section{Pendahuluan}

Sungai adalah daerah aliran air yang telah menjadi salah satu sumber kehidupan umat manusia dan makhluk hidup. Aliran air di sungai terjadi secara alami dari hulu ke hilir di mana kecepatan alirannya tergantung pada kemiringan kontur sungai [1]. Berbagai macam material yang dialirkan melalui sungai, salah satunya adalah sampah dari rumah tangga dan industri. Sampah sebagai material limbah, baik organik maupun anorganik seringkali bertaburan memenuhi di daerah aliran sungai (DAS). Hal ini menimbulkan beberapa masalah di berbagai aspek terutama di aspek lingkungan, berupa pencemaran ekosistem. Selain itu, meningkatnya jumlah sampah di daerah aliran sungai karena percepatan urbanisasi juga menimbulkan masalah lain yang lebih spesifik [2]. Antara sampah akan muncul sebagai penumpukan di daerah aliran sungai, yang berpotensi dapat menghalangi aliran air dan meningkatkan risiko banjir [3], merusak infrastruktur [4], atau sampah akan terus mengalir ke daerah pantai, merusak ekosistem dan pariwisata yang lebih luas.

Sebagai upaya untuk mengendalikan masalahmasalah ini, Perserikatan Bangsa-Bangsa (PBB) telah mengusulkan agenda 2030 untuk pembangunan berkelanjutan (SDGs), salah satunya memastikan keberlanjutan dan ketersediaan air bersih untuk sanitasi dan mencegah meningkatnya jumlah polusi di lautan, laut, dan sumber daya laut [5]. Sebelum agenda 2030 diterbitkan pada tahun 2015, banyak teknologi dan penemuan telah dikembangkan untuk mengatasi masalah sampah terutama pada aliran sungai. Teknologi yang paling umum adalah rak/jaring sampah, dalam wujud susunan batang persegi panjang dengan ketebalan 
tertentu [6], dimodifikasi dengan mekanisme konveyor sebagai alat penyaringan sampah di badan air yang bergerak [7], [8]. Desain dari penemuan ini banyak digunakan saat ini dan telah terbukti cukup efektif untuk menyaring sampah di sungai yang terletak di dekat daerah perkotaan. Namun, peralatan ini berpotensi memblokir sungai sepenuhnya dan meningkatkan risiko banjir [3]. Namun, desain rak sampah memiliki potensi yang sama untuk memblokir saluran. Persentase penyumbatan puing yang dianalisa oleh [3] dapat dikurangi melalui peningkatkan jarak bar. Langkah ini tentu efektif untuk mengurangi potensi rak sampah yang menghalangi saluran/sungai, akan tetapi fungsi utama alat untuk menyaring sampah juga akan berkurang karena semakin banyak sampah yang dapat hanyut bersama dengan aliran air.

Alat penyaring dan penangkap sampah yang telah dikembangkan lainnya adalah alat dengan mekanisme sekrup konveyor dengan posisi miring vertikal, dirancang untuk aliran kecil air limbah industri [9]. Meskipun bersifat mudah dipindahkan dibandingkan dengan mekanisme rak sampah yang diam pada tumpuan, penemuan ini hanya dapat sesuai dengan saluran kecil sistem air limbah industri. Sementara itu, pengembangan alat dengan mekanisme sekrup konveyor [9] diajukan oleh Irawan, et al. [10] dengan kombinasi sekrup konveyor miring dan horisontal dan kincir air, memungkinkan untuk menangkap dan menggiring sampah di sepanjang badan sungai langsung ke wadah sampah. Namun, pengembangan desain ini masih bertentangan dengan perilaku sungai yang berfluktuasi [1]. Sebagai konsekuensinya, saat kecepatan aliran sungai rendah, alat akan tidak fungsional dan memblokir sungai sehingga berpotensi menyebabkan penumpukan sampah hingga banjir.

Berdasarkan pada pengembangan desain mekanisme screw conveyor oleh C. Lind dan Quast [9] dan Irawan, et al. [10], perancangan ini bertujuan untuk mendesain alat penangkap sampah berbasis screw conveyor dengan mengintegrasikan konsep screw dengan variasi desain menyerupai rak pada bilah dan motor listrik sebagai penggerak untuk meningkatkan intensitas penangkapan sampah dan sejalan dengan perilaku aliran sungai yang berfluktuasi [1]. Desain yang dirancang merupakan variasi generasi kedua dari mekanisme sekrup-kincir air (CIRRUPTIS) yang diusulkan oleh [10]. Validasi dan verifikasi hasil perancangan dilakukan dengan metode simulasi elemen hingga menggunakan software ANSYS. Metode perancangan alat dilakukan dengan pendekatan virtual prototyping yang meliputi perancangan desain CAD (ComputerAided Design) dan verifikasi awal desain menggunakan CAE (Computer-Aided Engineering) serta pengujian sistem monitoring dengan data virtual. Melalui metode virtual prototyping, diperoleh spesifikasi detail desain dan unjuk kerja desain teoritis sebagai dasar acuan perancangan prototipe nyata.

\section{Metode Penelitian}

\subsection{Metode Perancangan Desain CAD}

Desain bilah screw pada alat penangkap sampah DAS divariasikan dengan geometri rak sampah untuk mengurangi beban kerja poros sistem. Gambar 1 menunjukkan desain konseptual dengan estimasi dimensi awal. Parameter yang ditetapkan untuk tahapan perancangan adalah ukuran badan sungai sebesar 5 meter serta beberapa data pendekatan kondisi sungai yang mengacu pada desain konseptual sebagai estimasi awal ditunjukkan pada Tabel 1.

\section{Metode Perancangan Desain CAD}

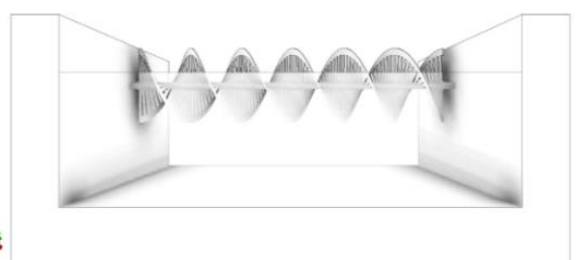

Gambar 1. Desain konseptual screw conveyor sebagai penangkap sampah DAS

Tabel 1. Parameter desain blade screw

Parameter

Radial clearance, $c$

Diameter Screw, D

Diameter shaft, $\boldsymbol{d}_{\boldsymbol{s}}$

Pitch, $p$

Jumlah pitch, $n$

Ketebalan bilah screw, $t_{s}$

Kebutuhan daya (P) untuk menggerakkan sistem screw dapat dinyatakan sebagai Persamaan (1)

$$
P=\frac{W d_{s} \pi N}{60}
$$

\section{Sistem transmisi}

Sistem screw akan membutuhkan sistem transmisi yang digunakan untuk meneruskan daya dari sumber tenaga motor listrik. Proses desain sistem transmisi berupa $V$-Belt dilakukan dengan merujuk pada daya motor listrik dan estimasi beban dari bilah screw serta dilakukan berdasarkan kalkulasi rumus dasar elemen mesin [11]. Berdasarkan dimensi standar $V$-Belt sesuai dengan IS: 2494 - 1974 [11], maka belt yang digunakan adalah tipe B. Pendataan dimensi sesuai standard IS: 2494 - 1974 dan data-data estimasi untuk desain ditabulasikan pada Tabel 2.

Tabel 2. Parameter desain sistem transmisi $v$-belt

\begin{tabular}{lc}
\multicolumn{1}{c}{ Parameter } & Nilai \\
\hline Pulley rim tension $\boldsymbol{\sigma}_{\boldsymbol{t}}$ & $1 \mathrm{MPa}$ \\
Densitas material pulley (cast & $7200 \mathrm{~kg} / \mathrm{m}^{3}$ \\
iron) & \\
Kecepatan angular driver $\left(\boldsymbol{N}_{\mathbf{1}}\right)$ & $973 \mathrm{rpm}$ \\
Kecepatan angular driven $\left(\boldsymbol{N}_{2}\right)$ & $250 \mathrm{rpm}$ \\
Lebar V-Belt (bagian atas), b & $17 \mathrm{~mm}$ \\
(Type B V-Belt IS: 2494 - & \\
1974) & \\
Tebal V-Belt, $\boldsymbol{t}_{\text {belt }}$ (Type B V- & $11 \mathrm{~mm}$ \\
Belt IS: 2494-1974) & \\
Groove angle, 2B & $34^{\circ}$ \\
Densitas V-Belt, $\boldsymbol{\rho}_{\text {belt }}$ (Material & $1140 \mathrm{~kg} / \mathrm{m}^{3}$ \\
Rubber) & \\
Allowable v-belt stress, $\boldsymbol{\sigma}_{\text {belt }}$ & $2 \mathrm{Mpa}$
\end{tabular}


Jarak antara pulley, $x$

$1065 \mathrm{~mm}$

Penentuan diameter pulley $\left(d_{2}\right)$ didasarkan dengan hubungan Persamaan (2) dan Persamaan (3),

$$
d_{1}=\frac{60 v}{\pi N_{1}} \quad \text { (2) } \quad d_{2}=\frac{d_{1} N_{1}}{N_{2}}
$$

serta dengan nilai $v$ ditentukan dengan Persamaan (4).

$$
v=\sqrt{\frac{\sigma_{t}}{\rho}}
$$

Untuk jumlah $v$-belt dan panjang $v$-belt $\left(L_{\text {belt }}\right)$ menggunakan kalkulasi yang diperoleh dengan Persamaan (5) dam Persamaan (6).

$$
\begin{gathered}
\text { Jumlah belt }=\frac{P_{M}}{P_{T}} \\
L_{\text {belt }}=\frac{\pi}{2}\left(d_{2}+d_{1}\right)+2 x+\frac{\left(d_{2}+d_{1}\right)^{2}}{4 x}
\end{gathered}
$$

\section{Perancangan poros}

Poros dirancangan berdasarkan pembebanan kombinasi torsi $(\mathrm{T})$ dan momen bending $(\mathrm{M})$ serta beban fluktuatif merujuk perumusan pada [11] dengan kalkulasi dari persamaan (7) dan Persamaan (8).

serta,

$$
T=\frac{P \times 60}{2 \pi N}
$$

$$
M=\frac{W \times L}{4}
$$

Dengan variabel $T$ dan $M$ yang diperoleh, dapat ditinjau diameter poros dengan dua pendekatan, yaitu pendekatan momen puntir equivalent serta momen bending equivalent yang ditunjukkan dengan persamaan (9),

$$
T_{e}=\sqrt{\left(K_{m} \times M\right)^{2}+\left(K_{t} \times T\right)^{2}}=\frac{\pi}{16} \times \tau \times\left(d_{s}\right)^{3}
$$

serta Persamaan (10).

$$
M_{e}=\frac{1}{2}\left[K_{m} \times M+\sqrt{\left(K_{m} \times M\right)^{2}+\left(K_{t} \times T\right)^{2}}\right]=\frac{\pi}{32} \times \sigma_{b} \times\left(d_{s}\right)^{3}
$$

Dengan dua nilai $d_{s}$ yang diperoleh akan digunakan nilai yang lebih besar dengan pertimbangan keamanan. Beberapa data acuan yang digunakan dalam proses desain poros ditunjukkan pada Tabel 3. Tabel 3. Parameter desain poros

\section{Parameter}

Kecepatan putar poros,

$\mathrm{N}$

Beban poros, $\mathrm{W}$

Jarak pembebanan, $\mathrm{L}$

Maximum shear stress, $\boldsymbol{\tau}$

(safety factor $=6$,

Aluminium 6061) [11]

Bending stress, $\sigma_{b}$

(safety factor $=6$,

Aluminium 6061) [11]

Gabungan faktor shock

dan fatigue untuk

bending, $\boldsymbol{K}_{m}$ [11]

Gabungan faktor shock dan fatigue untuk torsi, $\boldsymbol{K}_{\boldsymbol{t}}[11]$

\section{Nilai}

$$
250 \mathrm{rpm}
$$

$1552,22 \mathrm{~N}$

$2,5 \mathrm{~m}$

$34,5 \mathrm{MPa}$

$46,67 \mathrm{MPa}$

1,5 (Rotating shaft, gradually applied with minor shocks)

1,5 (Rotating shaft, gradually applied with minor shocks)

\section{Perencanaan sistem tumpuan}

Sistem tumpuan dari poros pada screw conveyor harus mampu menahan kondisi pembebanan tinggi dan kondisi dinamis berupa perputaran. Selain itu, kondisi lingkungan seperti kandungan air juga menjadi dasar pertimbangan dalam merancang sistem tumpuan yang tangguh. Pada perancangan alat ini, sistem tumpuan yang dipilih adalah rolling contact bearing. Pemilihan

\begin{tabular}{|c|c|}
\hline Parameter & Nilai \\
\hline Umur pakai bearing & 10 tahun \\
\hline $\begin{array}{l}\text { Waktu pemakaian bearing } \\
\text { per hari }\end{array}$ & $20 \mathrm{jam}$ \\
\hline Beban radial, $\boldsymbol{W}_{\boldsymbol{R}}$ & $3000 \mathrm{~N}$ \\
\hline Beban axial, $\boldsymbol{W}_{A}{ }^{n}$ & $2000 \mathrm{~N}$ \\
\hline Kecepatan putar, N & 250 rpm \\
\hline $\begin{array}{l}X \quad\left(\frac{W_{A}}{C_{0}}=\mathbf{0 . 5}\right),\left(\frac{W_{A}}{W_{R}}>\boldsymbol{e}\right), \\
\text { (sesuai Tabel standard } \\
\text { pada [11]) }\end{array}$ & 0,56 \\
\hline $\begin{array}{l}Y \quad\left(\frac{W_{A}}{C_{0}}=\mathbf{0 . 5}\right),\left(\frac{W_{A}}{W_{R}}>\boldsymbol{e}\right), \\
\text { (sesuai Tabel standard } \\
\text { pada [11]) }\end{array}$ & 1,0 \\
\hline $\begin{array}{l}\text { Faktor rotasional, } V \\
\mathrm{k}\end{array}$ & $\begin{array}{c}1,0 \\
3 \text { (ball bearing) }\end{array}$ \\
\hline
\end{tabular}
desain dilakukan sesuai dengan katalog produk sesuai dengan hasil perhitungan rating beban dinamis berdasarkan rumus dasar perhitungan elemen mesin pada [11] dan [12]. Tabel 4 menunjukkan parameter yang ditetapkan untuk kajian data desain tumpuan.

Tabel 4. Parameter desain sistem tumpulan rolling contact bearing

Penentuan umur pakai bearing dalam hitungan revolusi dapat menggunakan persamaan berikut.

$$
L_{a r}=60 N L_{H}
$$

Selain dengan persamaan tersebut, katalog SKF memiliki pendekatan lain dalam menentukan umur bearing dengan menentukan terlebih dahulu parameter basic dynamic equivalent radial load (W) serta basic dynamic load rating $(\mathrm{C})$, yang ditunjukkan berturut-turut dengan Persamaan (12) dan Persamaan (13), sehingga kalkulasi umur bearing diperoleh dengan persamaan (14).

$$
\begin{gathered}
W=X V W_{R}+Y W_{A} \\
C=W\left(\frac{L_{a r}}{10^{6}}\right)^{1 / k} \\
L_{a r}=\left(\frac{C}{W}\right)^{k} \times 10^{6}
\end{gathered}
$$

Dengan peninjauan seluruh komponen, diperoleh faktor geometris blade screw (г) yang dinyatakan dengan Persamaan (15).

$$
\Gamma=\frac{1}{n}\left[\left(1+2 \frac{c}{d}\right)^{2}-\left(\frac{d_{s}}{d}\right)^{2}\right]\left[\frac{p}{d}-\frac{t_{s}}{d}\right]
$$

Untuk memperoleh unjuk kerja desain berupa kapasitas penangkapan sampah, digunakan perhitungan berdasarkan kajian teoritis screw conveyor oleh Roberts [13], yang dinyatakan dengan Persamaan (16).

$$
\eta_{V}=\left(\frac{h_{a v}}{p}\right)\left(1-\frac{p\left(p+2 \pi \mu_{s} r\right)}{4 \pi^{2} r^{2}+p^{2}}\right)
$$

dengan kapasitas total sampah maksimal secara teoritis ditunjukkan dengan Persamaan (17).

$$
Q_{t}=\Gamma \omega D^{3}
$$


Alat akan didesain dengan kondisi setengah tenggelam (mengapung). Desain konseptual menunjukkan bahwa saat sistem bekerja dengan kecepatan putaran tertentu, sampah aliran akan secara otomatis tergiring ke pinggir sungai sehingga menghindari penumpukan sampah pada aliran air utama. Desain rekayasa detail (engineering design) membutuhkan eksekusi prosedur perancangan dengan kaidah-kaidah perancangan. Pada perancangan sistem ini, metode yang diterapkan merupakan virtual prototyping. Virtual prototyping merupakan pendekatan metode manufaktur dengan simulasi/komputasi data yang mampu ditampilkan, dianalisa, dan diuji terhadap engineering design, metode manufaktur, dan layanan tertentu [14]. Pada penelitian ini, tahapan perancangan secara garis besar meliputi konstruksi desain CAD (ComputerAided Design) menggunakan software Autodesk Inventor Professional 2018 melalui kalkulasi elemen mesin sistem, verifikasi awal desain dengan CAE (Computer-Aided Engineering) menggunakan software ANSYS, serta konstruksi sistem monitoring berbasis Internet of Things dengan Firebase sebagai data platform. Secara garis besar, skematik proses (flow chart) konstruksi desain CAD hingga tahapan verifikasi dengan CAE sistem penangkap sampah ini ditunjukkan pada Gambar 2.

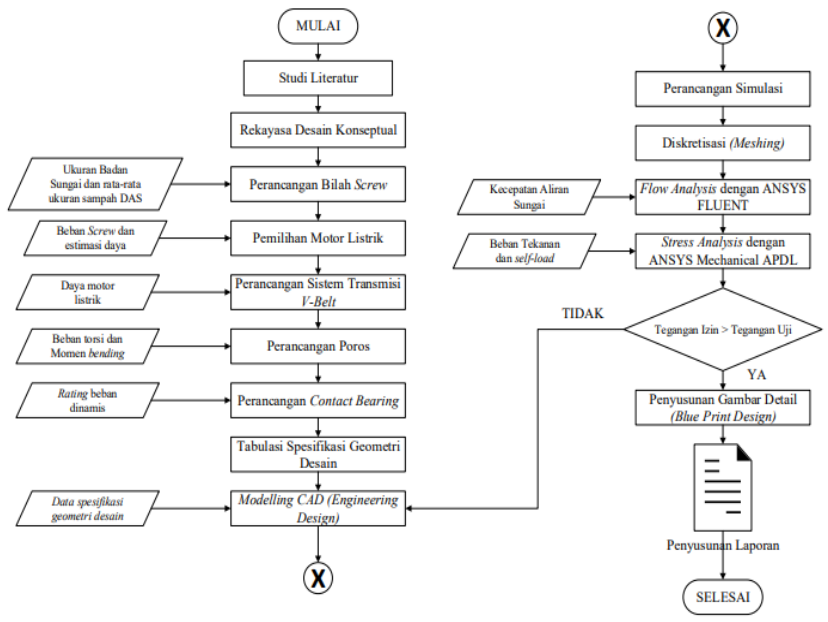

Gambar 2. Diagram alir (flowchart) perancangan desain sistem penangkap sampah DAS

\subsection{Metode Analisis dengan Simulasi ANSYS}

Metode analisis desain dilakukan menggunakan software ANSYS. Pada simulasi ini, digunakan dua tipe solver, yaitu ANSYS Fluent dan ANSYS Mechanical APDL. ANSYS Fluent digunakan untuk simulasi computational fluid dynamics (CFD), sedangkan ANSYS Mechanical APDL digunakan untuk analisis tegangan 3 dimensi. Kedua tipe solver tersebut memiliki prosedur analisis yang sama meliputi pre-processing, solver, dan post-processing. Pada analisis menggunakan ANSYS Fluent, preprocessing dilakukan dengan import geometry melalui software CAD Autodesk Inventor 2018, pembuatan enclosure sistem sebagai batasan pergerakan aliran, meshing, input kecepatan aliran air dan material desain yang digunakan, model analisis, dan parameter dalam melakukan iterasi. Proses meshing dilakukan dengan pengaturan default. Pada solver Fluent, dilakukan pengaturan berupa material yang digunakan (air dan Aluminium) serta kecepatan aliran air dari inlet sebesar $2 \mathrm{~m} / \mathrm{s}$. Model analisis yang dipilih adalah Laminar dan iterasi dilakukan sebanyak 80 kali dengan pseudo time step 0,5 . Terakhir proses post-processing dilakukan dengan membaca data hasil iterasi oleh solver ANSYS Fluent dan divisualisasikan dalam kontur kecepatan dari aliran air, dan vector arah pergerakan kecepatan aliran pada screw.

Data tekanan yang diperoleh pada simulasi CFD digunakan untuk simulasi analisa tegangan 3 dimensi dengan solver ANSYS Mechanical APDL dengan sistem analisis Static Structural. Pada tahap preprocessing dilakukan input data material melalui engineering data library pada ANSYS, import geometry melalui software CAD Autodesk Inventor 2018, meshing, pengkondisian beban self-load dan tekanan air serta penentuan tumpuan, dan penetapan solusi berupa Von Mises Stress dan Total Deformation. Material yang digunakan adalah Aluminium Alloy dengan standar karakteristik pada ANSYS. Proses Meshing dilakukan dengan pengaturan default. Beban self-load sebesar 826,93 $\mathrm{N}$ diberikan pada poros sistem dan dikombinasikan dengan beban tekanan sebesar $2166 \mathrm{~Pa}$ (surface effect). Post-processing analisis berupa visualisasi distribusi tegangan uji ekuivalen (Von Mises Stress) dan deformasi yang terjadi pada desain. Hasil tersebut akan dibandingkan dengan tegangan izin untuk validasi kekuatan desain terhadap beban dasar.

Tabel 5. Karakteristik material Aluminium Alloy pada Engineering Data ANSYS

\begin{tabular}{lc}
\multicolumn{1}{c}{ Parameter } & Nilai \\
\hline Densitas & $2770 \mathrm{~kg} / \mathrm{m}^{3}$ \\
Modulus Elastisitas & $71 \mathrm{GPa}$ \\
Poisson's Ratio & 0,33 \\
Tensile Yield Strength & $280 \mathrm{MPa}$ \\
Tensile Ultimate & $310 \mathrm{MPa}$ \\
Strength &
\end{tabular}

\subsection{Perancangan Sistem Monitoring berbasis Internet of Things}

Perancangan sistem monitoring pada alat menerapkan konsep Internet of Things dan hardware open-source NodeMCU. Pada sistem monitoring ini, data platform yang digunakan adalah Google Firebase. NodeMCU mampu memberikan perintah kontrol kepada sensor serta mengakusisi data dari sensor. Sensor yang digunakan adalah Ultrasonic Sensor (tipe HC-SR04) sebagai pendeteksi volume sampah pada penampungan sementara dan Hall Effect Sensor (tipe A3144) sebagai pendeteksi kecepatan putaran poros untuk mitigasi terjadinya kegagalan proses kerja mesin. Skema penyusunan hardware sistem monitoring divisualisasikan pada Gambar 3 menggunakan software fritzing. 


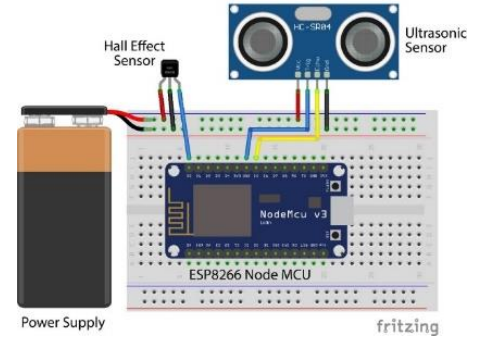

Gambar 3. Skema penyusunan hardware pada sistem monitoring alat

Algoritma sistem ditunjukkan pada Gambar 4. Algoritma kerja sistem monitoring dimulai dengan connect power dan wifi. Selanjutnya, melalui input data ketinggian sampah, sensor ultrasonik membaca dan mengakusisi data tersebut. Sensor hall effect mendeteksi dan mengakusisi input laju putaran (rpm). Data yang telah diakusisi kemudian ditransmisikan ke real-time Database Firebase dengan terhubung pada Access Point. Web App dirancang sebagai User Interface (UI) sistem monitoring. Web tersebut terhubung langsung dengan real-time database Firebase sehingga mampu menampilkan data yang diakusisi oleh sensor. Pengujian dan validasi sistem monitoring dilakukan terhadap data pengujian virtual untuk mendapatkan tampilan unjuk kerja dari sistem melalui user interface.

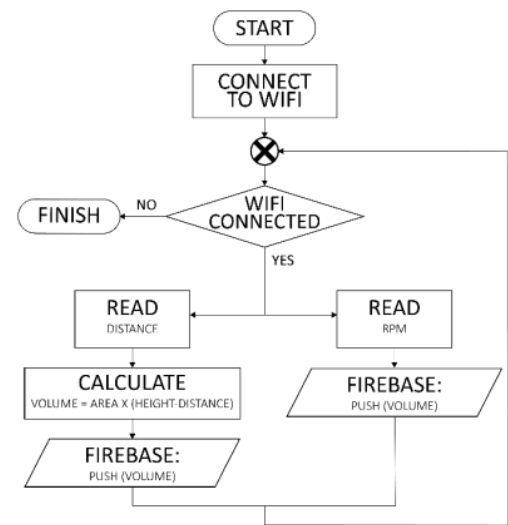

Gambar 4. Diagram algoritma sistem monitoring pada alat

\section{Hasil dan Pembahasan}

\subsection{Desain CAD sistem penangkap sampah}

\section{DAS}

\section{Bilah screw dan estimasi daya}

Desain bilah screw dirancang berdasarkan konsep screw yang telah dipatenkan oleh Okada, et al. [15] dan dikalkulasikan sesuai studi teoritis yang dilakukan oleh Roberts [13]. Dengan menggunakan data desain konseptual Tabel 1 dan estimasi beban menggunakan fitur iProperties pada Autodesk Inventor 2018 diperoleh beban screw sebesar $155,222 \mathrm{~kg}$ dengan tingkat relatif error $0,008737 \%$. Material yang digunakan adalah Aluminium 6061 dengan densitas material $2,7 \mathrm{~g} / \mathrm{cm}^{3}$. Terdapat parameter yang tidak masuk dalam kalkulasi namun berpengaruh pada perhitungan adalah panjang screw. Panjang screw didasari pada penetapan estimasi panjang sungai sebesar 5 meter. Dengan demikian, melalui Persamaan (1) diperoleh kebutuhan daya sebesar $6805,24 \mathrm{~kW}$ pada kecepatan putaran $250 \mathrm{rpm}$.

\section{Motor listrik dan sistem transmisi}

Motor listrik yang digunakan sesuai dengan katalog produk motor listrik OMEC. Berdasarkan proses pemilihan, motor listrik yang digunakan adalah tipe OMT1 IE3 6-Pole dengan rating 1000 rpm dengan designed power $7,5 \mathrm{~kW}$ dan voltase 220 240/380-420V. Pemilihan motor listrik ini didasari hasil perhitungan estimasi daya sebesar $6805,24 \mathrm{~kW}$. Desain transmisi ditinjau dengan parameter desain dan besar daya yang telah diperoleh. Sehingga, melalui Persamaan (2) dan Persamaan (3) nilai diameter pulley diperoleh sebesar 0,23 meter pada sisi driver $\left(\mathrm{d}_{1}\right)$ dan 0,9 meter sisi driven $\left(\mathrm{d}_{2}\right)$. Selain itu, melalui parameter tersebut serta Persamaan (5) dan Persamaan (6) berturut-turut diperoleh jumlah $v$ belt sebanyak 4 serta panjang $v$-belt adalah 4,2 meter. Jarak groove antara pulley sebesar $19 \mathrm{~mm}$ dengan menggunakan IS: 2494 - 1974. Pada Autodesk Inventor 2018, $v$-belt yang digunakan adalah $V$-Belt DIN 2215 yang memiliki panjang, tebal, dan lebar sesuai dengan hasil kalkulasi.

\section{Perancangan poros}

Hasil perhitungan menunjukkan bahwa diameter poros yang sesuai berdasarkan momen puntir/torsi equivalent melalui Persamaan (9) adalah $65 \mathrm{~mm}$. Sedangkan diameter poros berdasarkan pembebanan momen bending equivalent melalui Persamaan (10) adalah $70 \mathrm{~mm}$. Untuk desain struktur poros pada alat, digunakan hasil perhitungan diameter poros berdasarkan pembebanan momen bending equivalent sebesar $70 \mathrm{~mm}$.

\section{Perencanaan sistem tumpuan}

Sistem tumpuan dikalkulasikan dengan menggunakan data parameter pada Tabel 4. Sehingga, melalui Persamaan (11) dan Persamaan (12) dengan data tersebut menghasilkan umur pakai bearing sebesar $1095 \times 10^{6}$ revolusi serta basic dynamic equivalent radial load sebesar $3680 \mathrm{~N}$. Sementara, melalui katalog SKF, melalui Persamaan (13) dan Persamaan (14) berturut-turut diperoleh basic dynamic load rating dengan nilai $37,93 \mathrm{kN}$ dan umur pakai $1255,53 \times 10^{6}$ revolusi.

Menurut katalog SKF rolling contact bearing, tipe single row deep groove ball bearing dengan rating beban dinamis yang mendekati $37,93 \mathrm{kN}$ dengan diameter lubang $70 \mathrm{~mm}$ memiliki dimensi diameter utama (keseluruhan) (D) sebesar $110 \mathrm{~mm}$ dan ketebalan (B) $20 \mathrm{~mm}$. Rating beban dinamis sesuai katalog SKF adalah 39,7 kN. Berat bearing berkisar antara 0,61 - 0,7 kg. Bearing yang dipilih merupakan SKF-Single row deep groove ball bearing 6014-2Z.

\section{Desain dan spesifikasi}

Data parameter desain CAD merujuk pada perhitungan dan asumsi dasar pada perhitungan. Desain sistem penangkap sampah ini meliputi screw conveyor dengan desain bilah menyerupai rak sampah, motor listrik $7,5 \mathrm{~kW}, 4$ komponen $V$-Belt DIN 2215, 2 komponen pulley, dan 4 komponen SKFSingle row deep groove ball bearing 6014-2Z. Desain 
isometri gabungan komponen mesin dan desain detail ditunjukkan pada Gambar 5 dan 6.

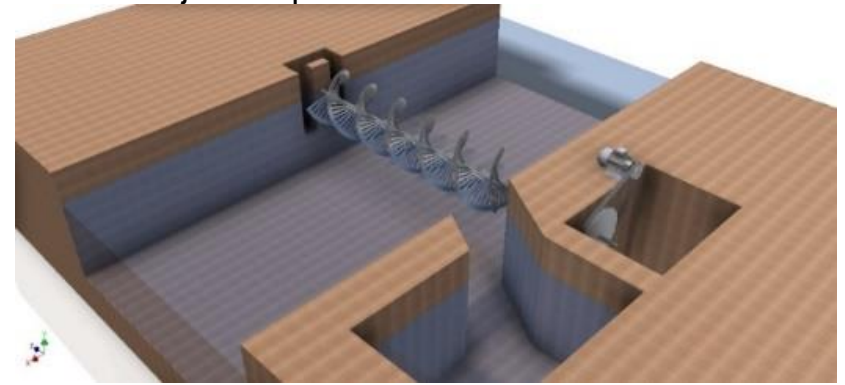

Gambar 5. Desain isometri sistem penangkap sampah berbasis screw conveyor dan loT

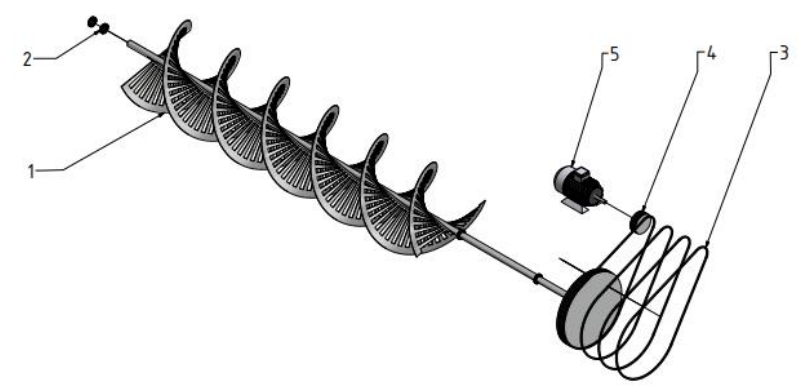

Gambar 6. Desain detail sistem penangkap sampah yang terdiri dari screw conveyor (1), SKF Single row deep groove ball bearing (2), 17/B-DIN 2215 classical wrapped $v$-belt (3), pulley (4), dan motor listrik (5).

Tabel 6. Spesifikasi Geometri alat penangkap sampah DAS

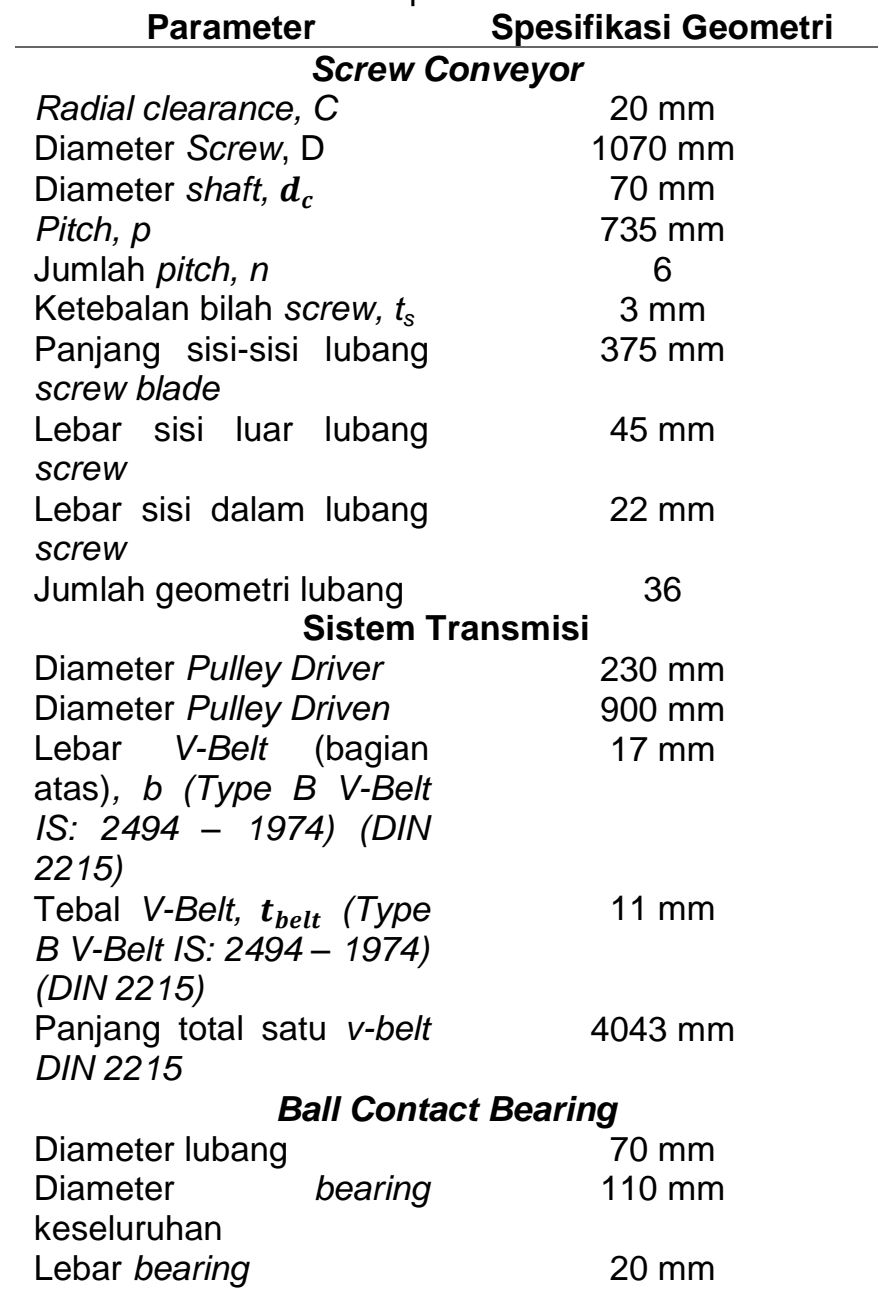

Spesifikasi geometri desain yang meliputi dimensi secara keseluruhan ditampilkan pada Tabel 6. Hasil keseluruhan akan ditabulasikan menjadi spesifikasi detail dari alat penangkap sampah pada Gambar 6. Untuk data Geometry Factor Blade Screw, melalui Persamaan (15) dan Persamaan (16), nilai $\Gamma$ yang diperoleh sebesar 0,122 dan efisiensi volumetric screw blade 0,592. Sehingga, dengan kapasitas penangkapan sampah teoritis $0,6227 \mathrm{~m}^{3} / \mathrm{s}$ dengan Persamaan (17), total kapasitas penangkapan sampah oleh alat diperoleh $0,368 \mathrm{~m}^{3} /$ $s$.

Merujuk pada spesifikasi geometri alat dan kalkulasi kapasitas penangkapan sampah oleh alat diatas, spesifikasi alat dapat dijabarkan pada Tabel 7. Spesifikasi pada Tabel tersebut merupakan spesifikasi secara umum, sehingga beberapa data pada spesifikasi geometri desain tercantum pada spesifikasi umum. Spesifikasi keseluruhan secara detail meliputi gabungan isi dari spesifikasi geometri desain dan spesifikasi umum.

Tabel 7. Spesifikasi umum alat penangkap sampah DAS

\begin{tabular}{|c|c|}
\hline Parameter & $\begin{array}{l}\text { Spesifikasi } \\
\text { Geometri }\end{array}$ \\
\hline \multicolumn{2}{|c|}{ Screw Conveyor } \\
\hline Berat & $100,358 \mathrm{~kg}$ \\
\hline Kapasitas Penangkapan & $0,368 \mathrm{~m}^{3} / \mathrm{s}$ \\
\hline Diameter blade & $1,07 \mathrm{~m}$ \\
\hline Pitch blade & $0,735 \mathrm{~m}$ \\
\hline Diameter poros & $0,07 \mathrm{~m}$ \\
\hline Panjang poros & $6,7 \mathrm{~m}$ \\
\hline \multirow{2}{*}{\multicolumn{2}{|c|}{ Sistem Transmisi }} \\
\hline & \\
\hline Diameter Pulley Driver & $230 \mathrm{~mm}$ \\
\hline Diameter Pulley Driven & $900 \mathrm{~mm}$ \\
\hline Tipe V-Belt & $\begin{array}{c}\text { 17/B - DIN } 2215 \\
\text { Clasiccal Wrapped }\end{array}$ \\
\hline & V-Belt $17 \times 4000$ \\
\hline Jumlah $V$-Belt & 4 \\
\hline \multicolumn{2}{|c|}{ Ball Contact Bearing } \\
\hline Tipe Bearing & $\begin{array}{l}\text { SKF-Single row } \\
\text { deep groove ball } \\
\text { bearing } 6014-2 Z\end{array}$ \\
\hline Umur pakai bearing & 10 tahun \\
\hline Rating life & $\begin{array}{c}1255,53 \times 10^{6} \\
\text { revolusi }\end{array}$ \\
\hline \multicolumn{2}{|c|}{ Motor Listrik } \\
\hline Tipe Motor Listrik & $\begin{array}{c}\text { OMT1 IE3 6-Pole } \\
1000 \mathrm{rpm}\end{array}$ \\
\hline Design Power Rating & $7,5 \mathrm{~kW}$ \\
\hline
\end{tabular}

\subsection{Simulasi CAE desain CAD sistem penangkap sampah DAS \\ Simulasi computer fluid dynamics (CFD)}

Desain screw pada analisis ini berada dalam kondisi force majeure dimana seluruh screw dalam kondisi tenggelam dan stasioner. Selain untuk mendapatkan parameter tekanan maksimum pada desain, tujuan analisis tenggelam ini juga untuk mempelajari respon arah pergerakan aliran air terhadap desain screw. Gambar 7 menunjukkan pergerakan aliran air menuju lubang-lubang pada bilah screw. Kecepatan aliran bergerak dari arah inlet 
dengan kecepatan uniform sebesar $2 \mathrm{~m} / \mathrm{s}$. saat melewati desain screw conveyor terjadi pengurangan kecepatan secara signifikan pada bagian poros desain hingga $0,2 \mathrm{~m} / \mathrm{s}$. Pada bagian bawah desain yang tidak terhalang, terjadi peningkatan hingga mencapai kecepatan $2,3 \mathrm{~m} / \mathrm{s}$. Bila ditelisik lebih detail pada bagian sekitaran screw conveyor, pengurangan kecepatan pada blade screw tidak terjadi signifikan dimana pengurangan terjadi hingga kecepatan 1,8 m/s (pada Gambar 8).

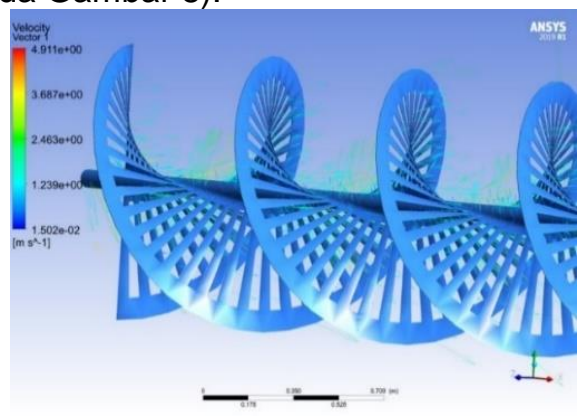

Gambar 7. Vektor kecepatan aliran air pada desain blade screw

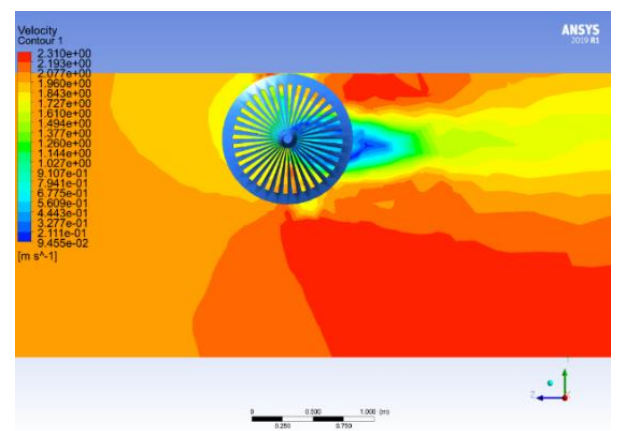

Gambar 8. Kontur kecepatan aliran air di sekitar screw conveyor

\section{Analisa tegangan 3 dimensi}

Hasil simulasi pada sistem analisis Static Structural menunjukkan bahwa Von Mises Stress pada poros berkisar pada 2,7102 MPa hingga 9,4807 $\mathrm{MPa}$. Nilai tersebut sangat jauh dibandingkan dengan tegangan izin (allowable tensile stress) sebesar 46,67 MPa (dengan acuan safety factor sebesar 6). Von Mises Stress maksimum pada kisaran 10,209 $\mathrm{MPa}$ hingga 12,189 MPa terjadi pada sambungan bilah screw dengan poros (Gambar 9). Nilai tersebut masih dibawah nilai tegangan izin sebesar 46,67 $\mathrm{MPa}$. Secara keseluruhan, proses perancangan screw conveyor tervalidasi dan sistem mampu bekerja tanpa mengalami gangguan signifikan ataupun kegagalan struktur material. Distribusi deformasi total yang terjadi akibat pembebanan pada alat penangkap sampah DAS ditunjukkan pada Gambar 10 . Total deformasi maksimum yang terjadi adalah 2,7501 $\mathrm{mm}$ pada sisi tengah desain.

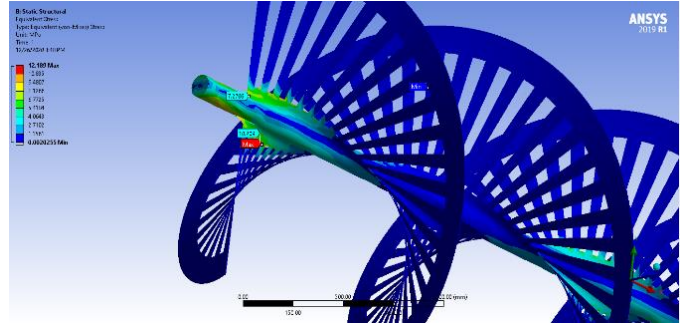

Gambar 9. Tampak dekat distribusi Von Mises Stress pada sambungan bilah screw dan poros screw

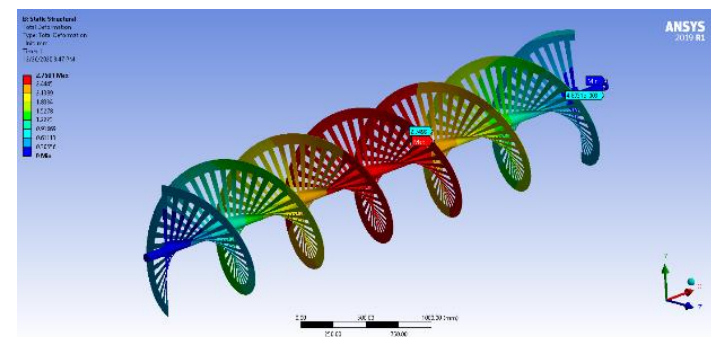

Gambar 10. Distribusi deformasi total pada desain screw conveyor

\subsection{Sistem monitoring berbasis Internet of Things (loT)}

Penerapan konsep internet of things untuk sistem monitoring menghasilkan user interface website yang dapat memberikan grafik untuk data yang berhasil ditransmisikan dari kerja sensor. User Interface website menampilkan dua grafik yang menunjukkan nilai data yang diakusisi oleh sensor. Selain itu, terdapat tanda yang menunjukkan status terakhir dari keadaan sistem penangkap sampah, dengan parameter yang ditetapkan sehingga mempermudah pekerja teknis dalam melakukan pengawasan.

Pengujian sistem monitoring secara virtual pada sensor hall effect berupa pengiriman data oleh NodeMCU mulai dari 6582 millisecond hingga 296981 millisecond. Dari seluruh data yang terekam, kecepatan rotasi poros dimulai dari 1,29 rpm hingga berfluktuasi kecil pada $250 \mathrm{rpm}$. Deteksi kecepatan putaran ini berguna untuk mitigasi shutdown yang tidak diharapkan pada alat yang berpotensi memblokir aliran sungai. Pada sensor ultrasonic, NodeMCU mengirim data mulai dari $4585 \mathrm{~ms}$ hingga $284687 \mathrm{~ms}$. Nilai saat pengiriman pertama menunjukkan $15,74 \%$ Volume tempat penampungan sampah sementara, hingga pada akhir perekaman nilai yang terkirim menunjukkan 55,94\% Volume sampah. Sistem monitoring jumlah sampah ini dapat digunakan acuan petugas untuk menentukan waktu pengangkatan sampah dari penampungan sementara menuju Tempat Pembuangan Akhir (TPA). 


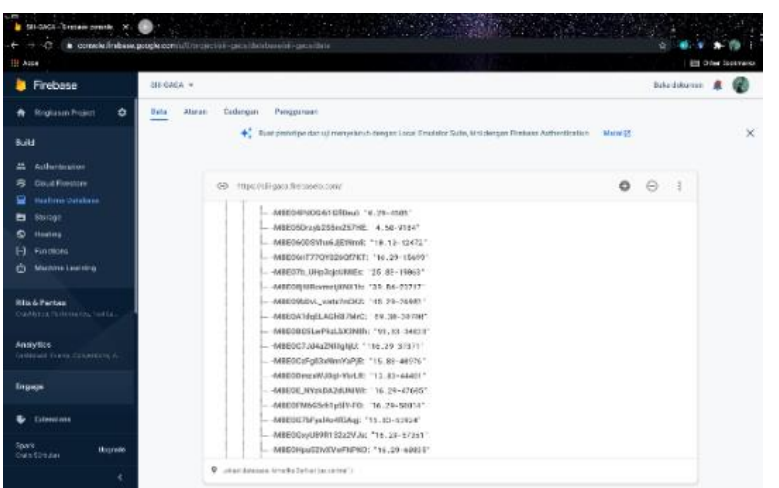

Gambar 11. Tampilan console transmisi data realtime pada database Firebase

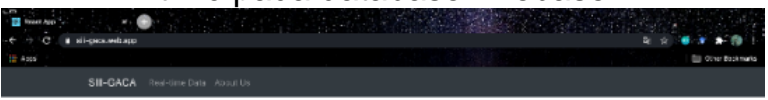

Kecepatan Putar Poros (rpm) taman

Volume Penampungan Sampah (\%)
Boumm Penuth
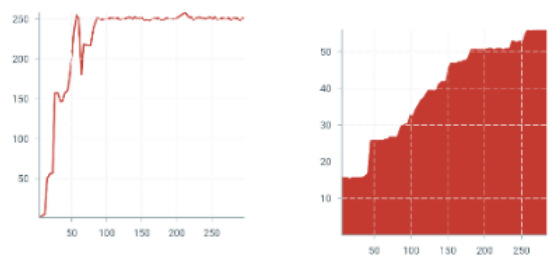

Gambar 12. User interface (UI) website sistem monitoring

\section{Simpulan}

Proses perancangan dari sistem penangkap sampah DAS berbasis integrasi screw conveyor dan sistem monitoring internet of things (IOT) telah dilakukan dan divalidasi melalui simulasi computational fluid dynamics dan analisa tegangan 3 dimensi. Selain itu, pengujian sistem monitoring secara virtual juga telah dilakukan dan menghasilkan tampilan grafik pada website. Hasil rancang bangun dan konstruksi virtual prototype sistem penangkap sampah DAS dengan desain Screw Conveyor dengan variasi lubang berbentuk trapesium pada bilah screw mampu secara efektif menjadi alternatif alat penangkap sampah pada Daerah Aliran Sungai dengan desain yang lebih sederhana dan tepat guna dengan kapasitas penangkapan sampah sebesar $0,368 \mathrm{~m}^{3} / \mathrm{s}$.

\section{Daftar Pustaka}

[1] W. Komarawidjaja, "Prospek Pemanfaatan Penyaring Sampah Sungai dalam Implementasi Imbal Jasa Lingkungan di Daerah Aliran Sungai Ciliwung Segmen 2 Kota Bogor," J. Teknol. Lingkung., vol. 18, no. 1, pp. 37-44, 2017.

[2] J.-J. Dethier, "Trash, Cities, And Politics: Urban Environmental Problems in Indonesia," Indonesia, vol. 103, no. 103, pp. 73-90, 2017.

[3] J. Blanc, "An analysis of the impact of trash screen design on debris related blockage at culvert inlets," Heriot-Watt University, 2013.

[4] M. Zayed, A. El Molla, and M. Sallah, "An experimental study on angled trash screen in open channels," Alexandria Eng. J., vol. 57, no. 4, pp. 3067-3074, 2018, doi: 10.1016/j.aej.2018.05.005.

[5] United Nations, "TRANSFORMING OUR
WORLD: THE 2030 AGENDA FOR SUSTAINABLE DEVELOPMENT," 2015. doi: 10.1201/b20466-7.

[6] J. M. Tsikata, C. Katopodis, and M. F. Tachie, "Experimental study of turbulent flow near model trashracks," J. Hydraul. Res., vol. 47, no. 2, pp. 275-280, 2009, doi: 10.3826/jhr.2009.3381.

[7] R. T. Steindorf, "TRASH REMOVING MECHANISM FOR WATER SCREENS," US1912020, 1933.

[8] S. Riyanto, R. Kurnianto, H. S. Putra, and F. E. Harianto, "Rancang Bangun Inntopes (Innovation Tools Pengangkat Sampah) Pada Aliran Sungai," Pelita - J. Penelit. Mhs. UNY, vol. 11, no. 1, pp. 112-125, 2016.

[9] A. C. Lind and G. W. Quast, "WASTE-FLOW SCREENING APPARATUS," US2929504, 1960.

[10] M. D. Irawan, I. D. M. O. Dharmawan, P. B. Sudarsana, and I. D. G. A. Subagia, "DESAIN DAN PERANCANGAN KINCIR SEKRUP OTOMATIS (CIRRUPTIS) UNTUK MENANGKAP SAMPAH PADA DAERAH ALIRAN SUNGAI," in Konferensi Nasional Engineering Perhotelan X, 2019, vol. 1, p. 1.

[11] R. S. Khurmi and J. K. Gupta, A TEXTBOOK OF MACHINE DESIGN, 1st ed. New Delhi: Eurasia Publishing House (PVT.) LTD., 2005.

[12] R. G. Budynas and J. K. Nisbett, Shigley's Mechanical Engineering Design, 9th Editio. New York: McGraw-Hill, 2011.

[13] A. W. Roberts, "The influence of granular vortex motion on the volumetric performance of enclosed screw conveyors," Powder Technol., vol. 104, no. 1, pp. 56-67, 1999, doi: 10.1016/S0032-5910(99)00039-X.

[14] G. G. Wang, "Definition and review of virtual prototyping," J. Comput. Inf. Sci. Eng., vol. 2, no. 3, pp. 232-236, 2002, doi: 10.1115/1.1526508.

[15] M. Okada, E. Nagoshi, and Y. Matsumoto, "SELF-DRILLING SCREW," US4323326, 1982.

\section{Nomenklatur}

$Q_{t} \quad$ kapasitas maksimum teoritis bilah screw tanpa rotasi $\left(\mathrm{m}^{3} / \mathrm{s}\right)$

$Q \quad$ kapasitas conveyor $\left(\mathrm{m}^{3} / \mathrm{s}\right)$

D diameter $(\mathrm{m})$

c radial clearance $(\mathrm{m})$

$t_{s} \quad$ ketebalan bilah screw $(\mathrm{m})$

$r$ screw radius $(\mathrm{m})$

$\Gamma \quad$ geometry factor (non-dimensional)

$\eta_{F}$ efisiensi kepenuhan

$\eta_{V}$ efisiensi volumetrik

$\eta_{V R}$ efisiensi putaran

$h_{a v}$ tinggi rata-rata sampah pada permukaan screw

$\mu_{s} \quad$ koefisien gesekan pada permukaan screw

$\omega \quad$ angular velocity screw (rev/s)

$n \quad$ jumlah pitch (vortex index)

p screw pitch $(\mathrm{m})$ 
$d_{s} \quad$ diameter poros $(\mathrm{m})$

$\rho \quad$ density $\left(\mathrm{kg} / \mathrm{m}^{3}\right)$

g gravitational acceleration $\left(9,8 \mathrm{~m} / \mathrm{s}^{2}\right)$

$T$ torsion $(\mathrm{Nm})$

$\mathrm{M}$ bending moment $(\mathrm{Nm})$

$\tau \quad$ allowable shear stress (MPa)

$\sigma_{b} \quad$ allowable bending stress (MPa)

$N \quad$ kecepatan putaran (rpm)

$T_{e} \quad$ momen torsi ekuivalen (Nm)

$M_{e} \quad$ momen bending ekuivalen (Nm)

$K_{m}$ gabungan faktor shock dan fatigue untuk bending

$K_{t} \quad$ gabungan faktor shock dan fatigue untuk torsi

W beban $(\mathrm{N})$

$\mathrm{L} \quad$ jarak pembebanan dari tumpuan $(\mathrm{m})$

$W_{R}$ beban radial (N)

$W_{A}$ beban aksial (N)

$\mathrm{C} \quad$ rating beban dinamis bearing $(\mathrm{kN})$

$L_{\text {ar }} \quad$ rating life (revolusi)

$\mathrm{V}$ faktor rotasional

$X \quad$ faktor beban radial

Y faktor beban thrust

$\sigma_{t} \quad$ allowable tensile stress (MPa) $v \quad$ kecepatan linier $(\mathrm{m} / \mathrm{s})$

$N_{1} \quad$ kecepatan putaran pulley 1 (rpm)

$N_{2} \quad$ kecepatan putaran pulley 2 (rpm)

$d_{1} \quad$ diameter pulley $1(\mathrm{~m})$

$d_{2}$ diameter pulley $2(\mathrm{~m})$

$P_{T} \quad$ Power transmitted per belt (W)

$P_{M} \quad$ Power transmitted by motor(W)

$T_{1} \quad$ tension pada tightside $(\mathrm{N})$

$T_{2}$ tension pada slackside $(\mathrm{N})$

$x$ jarak antara pulley $(\mathrm{m})$

$L_{\text {belt }}$ panjang total belt (m)

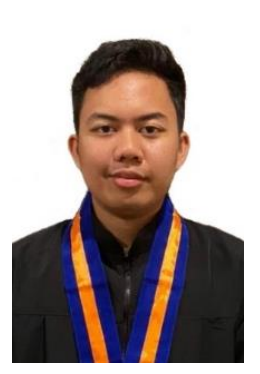

Putu Brahmanda Sudarsana merupakan mahasiswa S1 Teknik Mesin Universitas Udayana. Dibawah bimbingan Prof. I Dewa Gede Ary Subagia, PhD, la berhasil meraih penghargaan Medali Perak PIMNAS (Pekan IImiah Mahasiswa Nasional) 32 Tahun 2019 dan Medali Perunggu PIMNAS 33 Tahun 2020. 